\title{
Metaphors in Anatomical Terminology
}

Zifa Temirgazina, ${ }^{+*}$ Marzhan Akosheva, ${ }^{\top}$ Yrysgul Shakaman, ${ }^{\dagger}$ Aigerim Shaharman, ${ }^{\ddagger}$ Zauresh Kurmanova, ${ }^{\hat{\imath}}$ and Meruyert Kairova ${ }^{\dagger}$

\section{Abstract}

The article is concerned with the problem of metaphorisation as the most important cognition mechanism that plays a significant role in forming the anatomical vocabulary of the Kazakh and Russian languages. Terminology is a part of the literary language, whose formation and development is inseparable from the history and culture of its people. The article puts forward and scientifically substantiates the thesis that anatomical terminology differs from other terminological subsystems of the national language. It typically utilises terms developed from vernacular names that have not been formed through the logical comprehension of some scientific concept, i.e. they are categorised with the help of the everyday consciousness of native speakers. The key part of anatomical terminology is represented by proto-terms regarded as full-fledged terms in general scientific terminology. The article aims to analyse anatomical terms-metaphors of the Kazakh and Russian languages. To attain this objective, the authors of the article have compared metaphorical models of the Kazakh and Russian anatomical vocabulary, revealed their standard features and differences. The study uses the method of constructing metaphorical models and submodels for structuring the source area since conceptual metaphors have mental mappings between conceptual areas of the source and goal. The study material comprises single-word and compound anatomical terms of metaphorical origin (fifty-eight Kazakh nominations and fifty Russian) extracted from various dictionaries. As a result, the authors have identified and described four basic metaphorical models common to both languages. Some of them relate to the sphere of intradiscourse interaction of concepts ("parts of human body and organs", "fauna"), while the others belong to the sphere of interdiscourse interaction ("flora", "containers, reservoirs"). The study concludes that the language objectification of cognitive metaphorisation mechanism is a secondary result of mental processes, and such language phenomena as metaphors form generalised cognitive metaphorical models that function in the minds of speakers.

Keywords: Term, Metaphor, Anatomical Terminology, Metaphorical Model

\footnotetext{
${ }^{\dagger}$ Pavlodar State Pedagogical University, Pavlodar, Kazakhstan

${ }^{*}$ Corresponding Author, Email: zifakakbaevna@mail.ru

ÎS.Seifullin Kazakh Agrotechnical University, Astana, Kazakhstan

${ }^{¥}$ Toraigyrov Pavlodar State University, Pavlodar, Kazakhstan

(C) 2019 Temirgazine et al. This is an Open Access article distributed under the terms of the Creative Commons Attribution License (http://creativecommons.org/licenses/by/2.0), which permits unrestricted use, distribution, and reproduction in any medium, provided the original work is properly cited.
} 


\section{Introduction}

Language reflects all the changes taking place in society, including professional fields. Professional activity is expressed by means of a special language, that is, terminology, which is a part of the general literary language. Terminology is characterised by both general linguistic and specific patterns and processes.

Like a word, a term is a component of the lexical system of national language that has a nominative function. According to scholars (Danilenko, 1977; Lotte, 1982; Kandelaki, 1977; Kapanadze, 1965; Reformatskii,1968 and others), the main differentiating feature of terms is their connection with a special concept, that is, a term is a means of expressing scientific, technical and productive concepts. Consequently, terms, unlike ordinary words, have many specific characteristics caused by this feature, including unambiguity, the lack of imagery, emotiveness, expressiveness, metaphorical use, the lack of synonyms, unified use, and consistency. At the same time, terminology researchers (for example, S. Fernandez-Silvia) highlight the variability of terms due to the text genre (Fernandez-Silvia, 2013).

Most researchers note the consistency, independence and self-continence of scientific terminology as a lexical subsystem of national literary language (Fernandez-Silvia, 2013; Veklich, 1999; Nasyrova, 2013). However, one cannot deny the connection between various terminological systems and common vocabulary. V.N. Prokhorov explained this phenomenon in the following way: "[a]t the initial stages of the formation of many terminological systems, terminology users did not have a large choice of language means for denoting special concepts, and semantic word-building (the nomination with the use of a common word) was the most accessible, simple and convenient method" (Prokhorova, 1996: 13-14). In fact, the terminology is a part of a particular language; therefore, its formation and development are inseparable from the history and culture of certain people. Native speakers and culture bearers directly influence the formation and development of the conceptual content of terms. V. Leichik wrote, "[a]mong other things, the formation of terminological systems is affected by the worldview of language speakers" (Leichik, 2007: 9). The Russian philosopher P.A. Florenskii called the term "the product of historical and cultural creativity" (Florenskii, 2000: 375). In our opinion, such terms can be attributed to the keywords for a specific culture as a "[c]ultural keywords can serve as a tool for intercultural communication. They are indicators for describing and understanding cultures" (Akizhanova et al., 2018: 78).

In this article, we discuss anatomical terminology as an integral part of the scientific terminology of the Kazakh and Russian languages. They proceed from the thesis that the formation of anatomical terminology is a "natural, historical process interconnected with the development of national culture and generation of scientific ideas about the structure of human body" (Veklich, 1999: 3).

Scholars have studied the Kazakh anatomical terminology from different perspectives: from the diachronic viewpoint (Ayapbergenova, 1999), with regard to the sources of terms (Kaidarov, 1993; Kurmanbaiuly, 2005), ways of their formation (Nasyrova, 2013; Kurmanbaiuly, 2005). They paid much attention to the role of anatomical terminology in the general training of future doctors in medical schools. In particular, Kazakh scientists conducted much work to unify anatomical terms and their lexicographic representation in bilingual, trilingual terminological dictionaries and reference books (Akhmetov, 2005; Isambaev \& Sarsenova, 1982; Aubakirov et al., 2008).

The origin and formation of the Russian anatomical terminology were considered from the diachronic aspect in the following scientific works (Novodranova, 2007; Barankova, 1991; Bogoyavlenskii, 1970). Some publications present the results of studying various ways of forming medical and anatomical terms in the Russian and other languages (Knyazkina, 2012; 
Buzheninov, 2015; Rossi, 2014; Lukoyanova, 2015; Grosheva, 2015).

A necessary provision for this article is the thesis that anatomical terminology as a subsystem of scientific terminology differs from other scientific terminological subsystems of the national language. First, anatomical nominations are among the oldest and most stable layers of language vocabulary; second, anatomical terminology is characterised by the close connection between commonly used words and terms; third, nominations of body parts express the cultural and linguistic worldview of language speakers, their mythological, pagan, religious and cult representations.

A.B. Nasyrova emphasised the peculiar verbalisation of anatomical concepts in the Kazakh linguistic consciousness: "[s]ubstantive anatomical concepts are verbalised in the minds of native Kazakh speakers, their language has regular linguistic means of expression that belong to the original Kazakh vocabulary: telo dene (body), pozvonok - omyrtka (vertebra), kost - suyek (bone), sukhozhilie - sinir (tendon), mozg - mi (brain), korennoi zub - azu (molar tooth), zhilik - trubchataya kost (longitudinal bone), etc. These are universal lexical units of specific semantics. The Kazakhs had always great knowledge of organisms (animals), which is historically associated with the nomadic way of life and cattle breeding" (Nasyrova, 2013: 2823).

In contrast to other terminological systems, anatomical terminology is based on commonly used vocabulary. Thus, S.V. Grinev-Grinevich called lexical units are used in everyday and professional speech-consubstantial terms (Grinev-Grinevich, 2008). The close connection between anatomical terminology and common vocabulary led to the fact that most anatomical terms were often used not only by the professional community of anatomists or physicians but also by common speakers.

Our research is presented in the traditional composition of the article. It includes a review of the works on the problem under study in the introductory part, as well as a description of the actual material for the study and its methodological foundations. The key findings of the research (metaphorical models and submodels of terms) and their discussion occupy most of the article. The next section discusses the methods and materials applied.

\section{Materials and Methods}

Although many researchers of scientific terminology state that the lack of metaphoricity is a mandatory feature of terms as lexical units, the study of terms prove that metaphorisation as a method for creating new terms is a popular way to comprehend scientific concepts. Indeed, "[t]he role of metaphorical nominations in term formation has become a universally recognised fact. Mechanisms for creating metaphors remain one of the key problems of cognitive science" (Nasyrova, 2013: 2824).

Using zoological terms we have substantiated in some of their works that the cognitive mechanism of analogy forming the process of metaphorisation is among the main methods of scientific cognition and assimilation of the surrounding reality (Temirgazina, Bahtikireyeva, Sinyachkin, Akosheva, 2016; Temirgazina, Bahtikireyeva, Sinyachkin, 2017). Other scientists also contributed to the study of metaphorical terms. Thus, M. Rossi analysed the functions and status of metaphorical terms in professional language (Rossi, 2014); S.M. Mishlanova considered metaphors in the Russian medical discourse, including anatomical discourse (Mishlanova, 2002); the American scientists R. Sommer and Barbara A. Sommer tried to determine the connection between botanical and zoological metaphors and human qualities and characteristics (Sommer, 2006; Sommer, \& Sommer, 2006).

This article utilises the understanding of metaphor presented in the contemporary theory of metaphor by M. Johnson and G. Lakoff (2003). According to this theory, metaphors act as a primary cognitive mechanism that organises and structures the person's way of thinking and experience, as well as forms abstract thinking. In this sense, they are universal and have the property of ubiquity, omnipresence. "The metaphor is a cognitive tool we use to comprehend abstract concepts and perform abstract reasoning", G. Lakoff said (1993: 244). 
A conceptual metaphor is "cross domain mappings from a source domain to a target domain" (Lakoff, \& Johnson, 1999: 58). Its mentality consists in the fact that it is "a reality at either the neural or conceptual level" (Lakoff, \& Johnson, 1999: 58). From the structural viewpoint, the conceptual domain of any goal is similar to the structure of the source area; that is, metaphorical mappings are established between them. Due to this specific orientation of metaphorical thinking, it can be described through models that indicate the domain of metaphor source and the domain of its goal and establish metaphorical mappings.

Therefore, the language objectification of the cognitive mechanism of metaphorisation is a secondary result of mental processes, while individual language phenomena (metaphors, metaphorical expressions, images) can be fit into generalised cognitive metaphorical models that function in the minds of native speakers. Metaphorical models can be universal, widespread and typical of all or most languages, but they can be also specific or even unique conveying the certain cognitive understanding and categorisation of new knowledge by the speakers of a given language. In the study by Ch.T. Denroche, metaphor is considered in the mind of a bilingual person as "a model of the linguistic mind, which consists of six components: three 'stores' and three 'skill centres'. The stores are the Mental Lexicon, the Mental Phraseicon and the Mental Schema Store, large passive storehouses of information, concerned with lexis, phraseology and frames" (Denroche, 2012: 11). The theory of conceptual metaphor was further developed and practically realised in works of other American scientists: $R$. Gibbs (2008) and Z. Kövecses (2002).

To analyse the Kazakh and Russian anatomical terms of metaphorical nature, we used the method of constructing metaphorical models and created submodels for elaborating the structure of the source area (if needed). The article also compares metaphorical models of the Kazakh and Russian anatomical vocabulary, reveals common features and differences between the Kazakh and Russian language consciousness manifested in anatomical nominations. In connection with the similar nature of the research, it is essential to note the interaction of languages, which for a long time coexist and interact in the minds of bilingual carriers. O.V. Baykova, A.V. Kazakov and others, who studied this problem on the basis of the interaction between the Russian and German languages argued:

The interaction of the Russian and German languages in the speech of German bilinguals resulted in the increased invasion of the norms of one language system into the framework of the other language (Baykova et al., 2018: 65).

Undoubtedly, the joint work of scholars in the field of terminology is necessary for remedial work to unify scientific concepts in two closely contacting and interacting languages. In our case, we consider the Kazakh and Russian languages (Jankowski, 2012; Why Russians speak Russian differently in Kazakhstan, 2016).

The study material comprises one hundred and eight anatomical nominations of metaphorical origin (fifty-eight Kazakh nominations and fifty Russian) extracted from terminological and encyclopedic anatomical and medical dictionaries (Akhmetov, 2005; Akhmetov, 1994; Kolesnikov, 2003; Krylov G. A. Etymological online dictionary of the Russian language, n. d.; Gilyarov, 1986), including bilingual (KazakhRussian, Russian-Kazakh, Russian-English) (Isambaev, \& Sarsenova, 1982; Kussainova, 2000; Damblton, 2000), handbooks of anatomical charts (Cherkasov, \& Kravchuk, 2014; Sinelnikov, \& Sinelnikov, 1996) and textbooks (Aubakirov et al., 2008; Akhmetov, 2016; Dosmukhameduly, 2017).The metaphorical nominations selected by us are one-word and compound terms.

We should note the specific formation of anatomical terminology that is manifested in the use of common names belonging to the oldest layer of language vocabulary as terms. They can be defined as prototerms. They are "special lexemes that originated and were used in the pre-scientific period of developing special 
knowledge, therefore they call no concepts (they are associated with the establishment of science) but special representations" (GrinevGrinevich, 2008: 44). Scholars (S.V. GrinevGrinevich, 2008; V.M. Leichik, 2007) believe that prototerms can be fit into terminology as fullfledged terms or can be replaced by other terms. A large part of anatomical terminology includes prototerms introduced into scientific terminology as full-fledged terms.

\section{Results and Discussion}

M.V. Veklich highlighted that "the independence and relative isolation of anatomical terminology led to the creation of its own means and methods of nominating anatomical concepts" (Kandelaki, 1977: 4). We describe the most frequently used metaphorical models for nominating the Kazakh and Russian anatomical concepts.

\section{The Metaphorical Model [human parts and organs] $\rightarrow$ [other human parts and organs]}

This metaphorical model relates to the intradiscourse interaction of anatomical concepts since some anatomical concepts are comprehended through other anatomical concepts (body parts, bones, organs, etc). The similarity of form and location conditions the choice of a concept for understanding another anatomical concept. For example:

- Kazakh zhatyr moiyny, zhatyr moiynshygy - Russian sheika matki (literally, the neck of the womb);

- Kazakh zhambastyn moiyny - Russian sheika bedra (literally, femoral neck).

- Kazakh anatomical terms often utilise the words moiyn and moiinshy, while similar Russian terms only use diminutive forms sheika with the suffix $-k-$. In other words, Kazakh anatomical terms do not always express the affectionate diminutive characteristic of the mentioned organ (neck).

- Kazakh kemey karynshasy - Russian zheludochek gortani (literally, laryngeal ventricle);
- Kazakh til arkashygy - Russian spinka yazyka (literally, the back of the tongue);

- Kazakh zhyny serini - Russian polovye guby (literally, vulvar lips);

- Kazakh kyltamyr - Russian kapilyar (literally, vessel as thin as a hair);

- Kazakh ayk-basy - Russian stupnya (literally, the head of foot);

- Kazakh on/sol zhak zhurek karynshasy (Latin ventriculus dexter) is one of the four chambers of the human heart; Russian pravyi/levyi zheludochek serdtsa (literally the right/left ventricle of the heart);

- Kazakh zhurektin oң/sol zhak kulagy Russian pravoe/levoe ushko serdtsa (literally, the right or left ear of the heart).

\section{The Metaphorical Model [container, reservoir] $\rightarrow$ [human organs]}

A very popular source of metaphors in anatomical discourse is an area containing the knowledge of hard and soft containers and various reservoirs: kitchenware, packing materials, boxes, accessories, etc. This model contributes to the accurate description of various phenomena and human organs in terms of the "vessel - content" ratio or in terms of similar shapes. It can be divided into two submodels in conformity with the nature and purpose of containers/reservoirs.

\section{The Metaphorical Submodel [kitchenware] $\rightarrow$ [human organs]}

In the Kazakh and Russian languages: askazan (literally, a bowl for food), pochechnaya lokhanka (literally, kidney pelvis), byirek astayshasy (literally, kidney dish), krovenosnye sosudy (literally, vessels that transport blood).

Terms based on this metaphorical model denotes individual human bones. They do not utilise the "capacity - content" ratio but rather the similar shape and characteristics of some vessels and bones. For instance, Russian taz (literally, bowl) is a circular bone formed by two symmetrical pelvic bones (the sacrum and coccyx) that are a part of the sacroiliac and the pubic symphysis. 
Kolennaya chashechka (literally, the kneecap) is a large, flat, triangle-like bone located directly opposite the joint where the thigh is connected to the tibia. V.N. Teliya calls such metaphors as kolennaya chashechka indicative or identifying since metaphorised objects are cognised, specific and similar to some other objects. Their similarity is not conventional but real. Their mode of fictitiousness ("as if") is replaced with the comparative mode ("like"). For instance, the kneecap is like a cap (= looks like a cap) (Teliya, 1988: 191-193).

In the Kazakh language, these parts of the human skeletal system are denoted by nonmetaphorical terms: tizenin ұrshyk syiegi, tizetobygy (kneecap), zhambas (pelvis).

\section{The Metaphorical Submodel [bladder container] $\rightarrow$ [human organs]}

The source area in this submodel is soft and nonrigid containers.

For example:

- Kazakh mi koraby - Russian mozgovaya korobka (cavity in the skull where the brain is located; literally, brain box); Kazakh kekirek kysy - Russian grudnaya polost (literally, thoracic cavity). The concepts from the source area fully coincide in these Kazakh and Russian terms: "box" and "cavity".

The examples below further represent the same cognitive mechanism that chooses different concepts from the conceptual source area:

- Kazakh ot kaby (literally, gallsack); Kazakh et irkilemin kalta (literally, gallpocket) - Russian zhelchnyi puzyr;

- Kazakh zhurek kaby (literally, the cardial sac) - Russian serdechnaya sumka (literally, the heart sac);

- Kazakh buyn kaltasy - Russian sustavnaya sumka (literally, the articular pocket).

The above-mentioned pairs of Kazakh and Russian terms include different soft and nonrigid containers: kaby (literally, sac), kalta (literally, pocket), puzyr (literally, bladder) and sumka (literally, bag).
The Russian terminology has metaphors without metaphorical counterparts in the Kazakh language. For example, Russian mochevoi puzyr (literally, bladder) - Kazakh kuyk; Russian moshonka (Latin scrotum - the skin-muscular sack-like structure of men and most male mammals containing testicles). The word "scrotum" is a diminutive form of moshna sumochka, meshochek, koshelek (a small handbag, pouch, wallet). This concept corresponds to the Kazakh non-metaphorical term ұma.

Anatomical nominations perceive such concepts as "bladder", "bag", "sac", "box", "pocket" and "purse" as containers for some content: brain, articulated fluid and soft organs.

\section{The Metaphorical Model [fauna] $\rightarrow$ [human organs]}

Zoological metaphors in anatomical vocabulary can also be attributed to the intradiscourse interaction of different areas of knowledge (zoology and anatomy). Here are the terms based on this model:

- Kazakh kaz taban (literally, goose-foot) flat-footedness, flatfoot;

- Kazakh kұiryk (literally, tail) - ass; the back of the human body below the back; buttocks;

- Russian ushnaya rakovina (literally, earflap);

A similar Kazakh term includes the word zhargak (membrane instead of flap): kұlaktyn zhargagy (literally, ear membrane). The meaning of "flap" is expressed in the Kazakh language by the following zoological terms: bakalsyk and kabyrshak, which are not used in the anatomical term kұlaktyң zhargagy.

Kazakh omyrtkanyn ermekshi kabygy (literally, the arachnoidal sac of a spinal bone) - Russian pautinnaya obolochka pozvonka (literally, the arachnoidal membrane of a spinal bone); Kazakh midyn torly kabygy (literally, the thecal sac of the brain) - Russian pautinnaya obolochka mozga (literally, the arachnoidal membrane of the brain); Kazakh mұrynkanaty (literally, wings of the nose) - Russian krylya nosa (literally, wings of the nose). 
Russian konskyi khvost (Latin Cauda equina) is a bundle of four lower lumbar, five sacral and coccygeal spinal nerves together with the terminal thread.

The concept of "cerebellum" is expressed by the following Kazakh terms: mishyk and karakұs miy. The nomination karakұs miy is interesting from the cultural and anthropological viewpoint that means "the brain of a black golden eagle". Karakұs is a steppe eagle with black or blackbrown feathers. The second meaning of the word karakұs is "burial ground, burial", while the third meaning is "the back occipital bone". The Kazakhs believe that karakұs like the raven in the European culture lives and feeds at burial grounds. The meaning of "the back occipital bone" originated from the Kazakh legend about a black golden eagle arguing with a raven on how much of the prey (fox) would be his share. The raven insists that he will take the front part of the fox, and the black hawk (karakzs) chooses the back part (Daken, n. d.). Thus, karakұs miy (cerebellum) literally means "the brain in the back of the head".

Karakұs is also a mythical character of the traditional Kazakh culture. Alyp karaқұs (a giant black hawk) could take the soul of a newborn before the sacred date (forty days) if the child was left unattended. To prevent this tragedy, people placed a protective charm (a vessel with milk) under the window of the woman who had just given birth to divert the attention of alyp karaқұs (Kazakh ethnographic category, average inventiveness of conceptual men and women, 2011)

\section{The Metaphorical Model [flora] $\rightarrow$ [human organs]}

The most popular concepts used in this model relate to the "tree" area: bark, root, branches, trunk, the ground part of a trunk, bud, acorn, which form the so-called dendrical metaphors.

For instance, Kazakh bas mi kabygy, Russian kora golovnogo mozga (literally, cerebral cortex).

In the Kazakh language, the bark of a tree is denoted by several synonyms kabyk, kyrtys and kabat. As a result, anatomical terms in the Kazakh language are formed with their use, for example, mi kyrtystary (brain cortex), byirekbez kyrtysy (adrenal cortex), bas mi kabygy (cerebral cortex). However, only one word kora refers to this concept in the Russian language. The polysemy of the word "bark" in the Russian language and the high level of synonymity of this concept in the Kazakh language are manifested in other language spheres: ledyanaya kora - muz kabaty (ice crust).

The nomination pochki (literally, buds/kidneys) is an outstanding example of the metaphorical formation of terms in accordance with the dendrical model. The Kazakh language describes this body part with the term byirek that is not related to plant concepts. The plant bud in the Kazakh language is denoted by another word burshik (kaiyn byrshikteri - berezovye pochki, agash byrshikteri-pochki na derevyakh).

The concept "root" is represented in the Kazakh language by two words tamyr and tybir that are used in the formation of metaphorical terms.

For examples:

- kantamyrlary; kantaratu tamyrlary (literally, blood roots) - blood vessels;

- tamyr (literally, temporal root) - the temporal artery;

- kyltamyr (literally, a root as a hair) - a capillary;

- neseptamyr (literally, urinary root) - the ureter;

- mistybiri - Russian koren zuba (literally, the root of a tooth).

Here are other examples of dendritic metaphors:

- Kazakh samai arteriyasynyn tobe bytagy - Russian temennaya vetv visochnoi arterii (literally, the parietal branch of the temporal artery);

- Russian legochnyi stvol (literally, the trunk of lungs) - Kazakh ekne dingegi (literally, pulmonary truck).

In Russian, the term zheludok (literally, acorn) means an organ of digestion located in the upper part of the abdominal cavity of humans and other animals. The Slavic word traces its origin to the stem zelod (acorn) because the form of the stomach resembles the fruit of an oak (Krylov G. 
A. Etymological online dictionary of the Russian language, $\mathrm{n}$. d.). There is another viewpoint on the etymology of the word stomach: "the Common-Slavic suffixal derivative of zhelud that preserved in Old Russian. Most likely, the latter has the same root as glotat, golod, Greek cholades "guts", ancient Irish gelim "to swallow", German Kehle "throat", etc. In this case, zheludok (stomach) is literally "where swallowed food gets into". The less popular hypothesis is that the stomach resembles an acorn and is called accordingly" (Shanskii, \& Bobrova, 2004).

The conceptual sphere "flora" is represented in anatomical terms by the concepts yagoda (berry), lukovitsa (onion) and yabloko (apple) due to similar appearance or shape.

The Russian nomination yagoditsa (clunis) is derived from the word yagoda (berry) by adding the affix -its-. This concept in the Kazakh language corresponds to several nominations: bekse; kұirykyk; dum formed in accordance with different models. The Kazakh term dum (buttock) literally means "the overground lower part of a tree", see the idiom dymge bir tebu in the meaning "to slap one's buttocks".

- Kazakh piyazdy zhynys myshesi - Russian lukovitsa polovogo chlena (literally, a penis bulb);

- Kazakh kөzdiң almasy - Russian glaznoe yabloko (literally, an eyeball).

\section{Conclusion}

Anatomical vocabulary is included in the oldest and most stable layer of the national language. Many of its words can be called prototerms which were later established as full-fledged scientific terms due to the development of scientific knowledge but retained their "internal form", etymology and connection with other conceptual areas.

This article has demonstrated that metaphorisation is one of the most important cognition mechanisms and plays an essential role in forming anatomical vocabulary in the Kazakh and Russian languages. We have described four basic metaphorical models common to both languages, which are in constant contact for a long time (Jankowski,
2012). They relate to the sphere of intradiscourse interaction of concepts ("body parts and organs of a person", "fauna") and the sphere of interdiscourse interaction ("flora", "containers, reservoirs").

The functioning of metaphorical models in the languages, as mentioned above, is characterised by specific features determined by cultural and historical characteristics of Kazakh and Russian speakers. Researchers of the Kazakh language write that many metaphors are a "congestion of cultural information, reaching the depth of spirit of the Kazakh people and world culture" (Alkhatova et al., 2014: 216).

\section{References}

Akhmetov, M.A. (2005). Meditsina terminderinin sezdigi. Almaty, Sezdik-Slovar.

Akhmetov, Zh.B. (1994). Meditsinada zhii koldanylatyn atalymdar. Almaty, Ana tili.

Akhmetov, Zh.B. (2016). Patologiyalyk anatomiya. Moscow: Litterra.

Akizhanova, D.M., Zharkynbekova, Sh.K., \& Satenova, S.K. (2018). The Zipf's Law and Other Ways of Identifying Culture-Specific Linguistics Units. Space and Culture, India, 6(2), 78-93.

Alkhatova, R., Sagyndykova, Z., \& Iveta, L. (2014). Perception of Kazakh metaphorical phrases with 'milk' component. In Rural Environment. Education. Personality. Jelgava, pp. 211-217.

Aubakirov, A.V., Zhumabaev, Y.Zh., Dosaev, T.M., Suleimenova, F.M., Sisabekov, K.E., Shaidarov, M.Z. (2008). Adam anatomiyasy, 1-2. Astana, "Foliant" baspasy, 251.

Ayapbergenova, K.K. Meditsinalyk terminderdi kazak tilinde kalyptastyru. Almaty, 1999. 115 pp.

Barankova, G.S. (1991). Anatomicheskie terminy $\checkmark$ russkikh spiskakh perevodnykh pamyatnikov [Anatomical terms among the Russian translation monuments]. Istochniki po istorii russkogo yazyka XI-XVII vv. Moscow, Nauka, 7990.

Baykova, O.V., Kazakov, A.V., Banin, V.A., Obukhova, O.N., Berezina, Y.V., \& Onoshko, V.N. (2018). Interfering Influence of Native German Dialects on the Language of Non-native Dialect 
Environment: Russian Speech of the German Bilinguals. Space and Culture, India, 6(2), 65-77.

Bogoyavlenskii, H.A. (1970). Otechestvennaya anatomiya i fiziologiya $v$ dalekom proshlom: Razvitie anatomo-fiziologicheskikh predstavlenii ot istokov do vtoroi treti XVIII $v$ [The Russian anatomy and physiology in the remote past: the development of anatomical-physiological concepts from the beginning to the second third of the 18th century]. Leningrad, Meditsina.

Buzheninov, A.E. (2015). Terminy-metafory v anatomicheskoi terminologii frantsuzskogo yazyka [Metaphorical terms in the anatomical terminology of the French language]. Pedagogicheskoe obrazovanie v Rossii, 10, 12128.

Cherkasov, V.G., \& Kravchuk, S.Yu. (2014). Anatomiya cheloveka [Human anatomy]. Vinnitsa, Nova Kniga.

Daken, A. (n. d.) Qaraqus pen túlki jaıly támsil [Complete story about pirates and foxes]. Retrieved from: https://massaget.kz/layfstayl/debiet/tmsil/180 96/.

Damblton, K.U. (2000). Russko-angliiskyi biologicheskyi slovar [The Russian-English biological dictionary]. Moscow, Tehnicheskie slovari.

Danilenko, V.P. (1977). Russkaya terminologiya: Opyt lingvisticheskogo opisaniya [The Russian terminology: Linguistic description]. Moscow, Nauka.

Denroche, Ch.T. (2012). Metaphor, Metonymy, Language Learning and Translation. London, Institute of Education, University of London.

Dosmukhameduly, Kh. (2017). Tán saulyǵy [That's right]. Almaty, Arys baspasy.

Fernandez-Silvia, S. (2013). Text genre and terminological variation: a corpus-driven research in the domain of psychology. In Languages for Special purposes in a multilingual, transcultural world. Vienna.

Florenskii, P.A. (2000). U vodorazdelov mysli [Along a thought border]. In Florenskii, P.A. Sochineniya: in four volumes. Moscow, Mysl.
Gibbs, R. (2008). Cambridge Handbook of Metaphor and Thought. New York, Cambridge University Press.

Gilyarov, M.S. (1986). Biologicheskii entsiklopedicheskii slovar [The biological encyclopedical dictionary]. Moscow, Sovetskaya entsiklopediya, pp. 293-831. Retrieved from: https://sozdik.kz/ru/dictionary/translate/ru/kk/

Grinev-Grinevich, S.V. (2008). Terminovedenie [Terminology studies]. Moscow.

Grosheva, A.A. (2015). K voprosu ob asimmetrii terminologicheskogo znaka $v$ meditsinskoi terminologii [The issue of assymetrical terms in medical terminology]. Izvestiya Samarskogo nauchnogo tsentra Rossiiskoi akademii nauk, 17(2(2)), 449-452.

Isambaev, M., \& Sarsenova, Sh. (1982). Meditsina terminderinin oryssha-kazaksha sezdigi. Almaty.

Jankowski, H. (2012). Kazakh in contact with Russian in modern Kazakhstan. In Turkic Languages. Wiesbaden, Harrassowitz Verlag.

Kaidarov, A. (1993). Kazak terminologiyasyna zhanasha kezkaras. Almaty.

Kandelaki, T.V. (1977). Semantika i motivirovannost terminov [The semantics and justification of terms]. Moscow, Nauka, pp. 4256.

Kapanadze, L.A. (1965). O ponyatiyakh termin i terminologiya [On the notion of terms and terminology]. In Razvitie leksiki sovremennogo russkogo yazyka. Moscow, Nauka.

Kazaktyn etnografiyalyk kategoriyalar, uǵymdar men ataularynyn dástúrli zhúiesi [Kazakh ethnographic category, average inventiveness of conceptual men and women]. (2011). Almaty, DPS.

Knyazkina, L.E. (2012). Sistemoobrazuyushchie sredstva $v$ russkoi anatomicheskoi terminologii (slovoobrazovatelnyi aspekt) [Systemic means of the Russian anatomical terminology (worldbuilding aspect)]. Izvestiya Samarskogo nauchnogo tsentra RAN, 14(2(5)), 1264-1267. 
Kolesnikov, L.L. (2003). Mezhdunarodnaya anatomicheskaya terminologiya [The international anatomical terminlogy]. Moscow.

Kövecses, Z. (2002). Metaphor: A Practical Introduction. Oxford, Oxford University Press.

Krylov G. A. (n. d.). Etymological online dictionary of the Russian language. Retrieved from: https://krylov.lexicography.online/.

Kurmanbaiuly, Sh. (2005). Terminologiyalyk kordy kalyptastyrudyn zháne terminologiya ádisterinin kózderi [The terminology of the heart caliphate is a prerequisite for terminology.]. Almaty, Sezdik-Slovar.

Kussainova, A.K. (2000). Kazahsko-russkyi, russko-kazahskyi terminologicheskyi slovar [The Kazakh-Russian and Russian-Kazakh terminological dictionary]. Almaty, Rauan.

Lakoff, G. (1993). The Contemporary Theory of Metaphor. In Metaphor and Thought. Cambridge, Cambridge University Press, pp. 202251.

Lakoff, G., \& Johnson, M. (1999). Philosophy in the Flesh: The Embodied Mind and Its Challenge to Western Thought. New York, Basic Books.

Lakoff, G., \& Johnson, M. (2003). Metaphors We Live by. Chicago, University of Chicago Press.

Leichik, V.M. (2007). Terminovedenie: predmet, metody, struktura [Terminology: subject, methods, structure]. Moscow, KomKniga.

Lotte, D.S. (1982). Voprosy zaimstvovaniya i uporyadocheniya inoyazychnykh terminov $i$ terminoelementov [The borrowing and systematisation of foreign terms and terminoelements]. Moscow, Nauka.

Lukoyanova, T.V. (2015). Metafora kak odno iz vazhnykh orudii myshleniya [Metaphors as an important tool for thinking]. Yazyk meditsiny, 5, 335-340.

Mishlanova, S.L. (2002). Metafora v meditsinskom diskurse [Metaphors in medical discourse]. Perm, Perm. gos. un-t.

Nasyrova, A.B. (2013). Medical Terms in Kazakh Language. European Researcher, 64(12-1), 28212827.
Novodranova, V.F. (2007). Iz istorii meditsinskogo terminovedeniya [The history of medical terminology]. Yazyk meditsiny, 2, 19-27.

Prokhorova, V.N. (1996). Russkaya terminologiya (leksiko-semanticheskoe obrazovanie) [The Russian terminology (lexicalsemantic formation)]. Moscow, pp. 13-14.

Reformatskii, A.A. (1968). Termin kak chlen leksicheskoi sistemy yazyka [Terms as components of a lexical language system]. In Problemy strukturnoi lingvistiki. Moscow, Nauka, pp. 10-29.

Rossi, M. (2014). Métaphores terminologiques: functions et statut dans les langues de spécialité. SHS Web de conferences, 8, 713-724.

Shanskii, N.M., \& Bobrova, T.A. (2004). Shkolnyi etimologicheskii slovar russkogo yazyka. Proiskhozhdenie slov [Student's etymological dictionary of the Russian language. The origin of words]. Moscow, Drofa.

Sinelnikov, R.D., \& Sinelnikov, Ya.R. (1996). Atlas anatomii cheloveka [Handbook of human anatomical charts]. Moscow, Meditsina.

Sommer, R. (2006). The Personality of Vegetables: Botanical Metaphors for Human Characteristics. Journal of Personality, 56(4), 665-683.

Sommer, R., \& Sommer, B.A. (2008). Zoomorphy: Animal Metaphors for Human Personality. Anthrozoos: A Multidisciplinary Journal of the Interactions of People \& Animals, 21(3), 237-244.

Teliya, V.N. (1988). Metaforizatsiya i ee rol v sozdanii yazykovoi kartiny mira [Metaphorisation and its role in forming linguistic worldview]. Rol chelovecheskogo faktora $v$ yazyke: Yazyk i yazykovaya kartina mira. Moscow, Nauka, pp. 173-204.

Temirgazina, Z.K., Bahtikireyeva, U.M., \& Sinyachkin, V.P. (2017). Artifacts as a source of Russian and Kazakh Zoological terms. American Journal of Applied Sciences, 20(4(A)), 2325-2336.

Temirgazina, Z.K., Bahtikireyeva, U.M., \& Sinyachkin, V.P., \& Akosheva, M.K. (2016). Cognitive Mechanism of Metaphorisation in 
Zoological Terms. American Journal of Applied Acknowledgements

Sciences, 13(12), 1385-1393.

Veklich, M.V. (1999). Formirovanie russkoi

The research group expresses their gratitude to anatomicheskoi terminologii (XVIII vek) [The formation of the Russian anatomical Nukhuly Altynbek, Professor, Doctor of Chemical Sciences, President of Pavlodar State terminology (the 18th century)]. Astrakhan.

Pedagogical University for his financial support Why Russians speak Russian differently in of this scientific article studying the Kazakh terminology.

Kazakhstan. (2016). Russkiy Mir. Retrieved from: https://russkiymir.ru/en/publications/201280/. 